\author{
MARTA DOROSZKO, KATARZYNA JANDA, KAROLINA JAKUBCZYK \\ Zakład Biochemii i Żywienia Człowieka \\ Pomorski Uniwersytet Medyczny w Szczecinie \\ Broniewskiego 24, 71-460 Szczecin \\ E-mail: kjanda4@gmail.com
}

\title{
WŁAŚCIWOŚCI PROZDROWOTNE WYBRANYCH OWOCÓW KRAJOWYCH
}

\section{WSTEP}

Owoce stanowią bardzo ważny składnik naszej codziennej diety. Zaliczane sa do grupy surowców spożywczych charakteryzujących się niska kalorycznościa, sa bogatym źródłem węglowodanów, w tym błonnika oraz składników mineralnych i witamin, pełniacych w organizmie człowieka funkcję regulatorów prawidłowych procesów metabolicznych a także chronia nasz organizm przed stresem oksydacyjnym. Owoce są także cennym źródłem fitozwiazków, które wykazuja podobne cechy do witamin, nie sa bowiem syntetyzowane przez nasz organizm i musza być dostarczane wraz $z$ pożywieniem (GHERIBI 2011). Ponadto, żywność pochodzenia roślinnego jest bogata w zwiazki o właściwościach przeciwutleniajacych; sa to głównie: polifenole, witaminy A i C, karotenoidy, tokoferole, kwasy organiczne, selen, wapń, glutation, chlorofil, indole, fityniany. Prozdrowotne właściwości owoców bogatych w przeciwutleniacze wykorzystuje się w zwalczaniu chorób cywilizacyjnych, takich jak miażdżyca czy cukrzyca (SzAJDEK i BOROWSKA 2004). Spożycie owoców na całym świecie znaczaco wzrasta nie tylko ze względu na bogate walory smakowe i dietetyczne, ale także $z$ uwagi na doskonałe właściwości zdrowotne. Światowa Organizacja Zdrowia (WHO) zaleca spożywanie owoców i warzyw w ilości 400g dziennie (GWÓźDź i GĘBCZYŃSKI 2015). Natomiast najnowsze badania epidemiologiczne wykazuja, że ilość ta jest niewystarczająca. Potwierdzono, że 5 porcji warzyw i owoców redukuje ryzyko chorób cywilizacyjnych, lecz pełen potencjał prewencyjny możemy osiągnąć spożywając 10 porcji warzyw i owoców dziennie (AUNE i współaut. 2017). Dane WHO dowodza, iż ograniczona podaż, okresowe braki owoców lub ich niska jakość, stanowią przeszkodę $\mathrm{w}$ zapewnieniu prawidłowego poziomu i wzrostu konsumpcji tych produktów. Całoroczna dostępność owoców, szeroka promocja i wysoka gwarancja jakości przyczyniają się do zwiększenia spożycia owoców zarówno przez dzieci, jak i dorosłych. Niemniej jednak, w Polsce konsumpcja owoców jest niezadowalająca $z$ punktu widzenia zdrowego odżywiania, jest też zwiąana $z$ porami roku. Jednak sytuacja ulega znacznej poprawie poprzez szeroki asortyment przetworów oraz rozwój importu $z$ całego świata (GWÓŹDŹ i GĘBCZYŃSKI 2015).

\section{ARONIA}

Aronia (Aronia) to roślina pochodząca $z$ Ameryki Północnej, w Europie uprawiana jest od XVII w. Należy do rodziny Roseaceae (Różowate). Wyróżnia się trzy gatunki aronii: aronię czarnoowocowa (Aronia melanocarpa), aronię czerwona (A. arbutifolia) i aronię śliwolistna (A. prunifolia) (BIAEEK i współaut. 2012). Rosnace w gronach owoce aronii o ciemnogranatowej, prawie czarnej barwie i słodkawym, aromatycznym miąższu maja średnicę ok. $10 \mathrm{~mm}$ i pokryte sa woskowym nalotem. Krzew, na którym rosną, może osiagać od dwóch do trzech metrów wysokości, nie charakteryzuje się specjalnymi wymogami glebowymi (SKUPIEŃ i OSZMIAŃSKI 2007). Aronia może być uważana za proekologiczny gatunek krzewów, ponieważ charakteryzuję się wysoka tolerancją na choroby i szkodniki. Ponadto, jej owoce nie kumulu- 
ją metali ciężkich, takich jak: kadm, ołów, cyna, arsen (BIAEEK i współaut. 2012). W Polsce na skale przemysłowa uprawiana jest aronia czarnoowocowa. Jej owoce $z$ uwagi na to, że zawierają dużo tanin, sa cierpkie w smaku. Dojrzały owoc aronii składa się w $74-83 \%$ z wody, $z$ czego $10 \%$ masy świeżych owoców stanowia cukry: glukoza i fruktoza; ich zawartość wynosi 66-100g/kg (GAWRYś i współaut. 2012). Owoce aronii wykorzystywane sa zarówno w przemyśle farmaceutycznym, jak i spożywczym. Ze świeżych owoców otrzymujemy: soki, syropy, dżemy, a także preparaty wzmacniajace i obniżajace ciśnienie krwi. Na rynku dostępne sa również suplementy diety: Bioaron C czy Aronox (WoLSKI i współaut. 2007). Owoce tego gatunku są bogatym źródłem składników o właściwościach antyoksydacyjnych, m.in.: antocyjanów $(0,5 \mathrm{~g} / 100 \mathrm{~g}$ owoców), znacznie więcej niż w czarnym bzie czy czarnej porzeczce (GAWRYŚ i współaut. 2012), flawonoli, fenolokwasów i garbników, jak również witamin: C, B2, B6, E, P, PP oraz składników mineralnych jak: Mo, $\mathrm{Mn}, \mathrm{Cu}, \mathrm{B}$, I, Co (KMIECIK i KoBUs 2005). Jednak to polifenole sa najprawdopodobniej najważniejszymi składnikami owoców aronii, odpowiedzialnymi za większość korzystnych dla zdrowia właściwości (KULLING i RAWEL 2008). Ich zawartość zależy od odmiany, warunków uprawy oraz pory zbiorów i waha się od 2000 do 8000 mg/100g suchej masy (KOROTKIEWICZ i współaut. 2010).

\section{PROZDROWOTNE WŁAŚCIWOŚCI ARONII}

Przez wiele lat owoce aronii oraz przetwory $z$ nich wytwarzane były uznawane za żywność konwencjonalną. W momencie odkrycia licznych prozdrowotnych substancji, które wyizolowano $z$ różnych rodzajów owoców jagodowych, również aronia stała się obiektem badania ich właściwości (KoRotKIEWICZ i współaut. 2010). Dojrzałe owoce aronii wykazują właściwości antyhepatoksyczne, przeciwnowotworowe, przeciwzapalne, przeciwwirusowe i antybakteryjne (ZIELIŃSKA-PRZYEJMSKA i współaut. 2007). Ponadto, w diecie przeciwmiażdżycowej zaleca się picie soku $z$ aronii, ze względu na obecność antocyjanów o silnych właściwościach przeciwutleniajacych (MICHALIK 1999). Sok $z$ aronii stosuje się przy oparzeniach zewnętrznych (KozŁowsKI 2002), jak również w nadczynności gruczołu tarczycowego, przy infekcjach dróg moczowych czy chorobach siatkówki oka (KUŹNICKA i DZIAK 1987). Poniżej przedstawione zostały przykłady prozdrowotnych właściwości aronii.

\section{POTENCJAE PRZECIWCUKRZYCOWY}

Cukrzyca jest chorobą wynikajacca z upośledzenia produkcji insuliny bądź niewrażliwości komórek docelowych na ten hormon, w wyniku czego dochodzi do zaburzenia poziomu glukozy we krwi. Potencjał przeciwcukrzycowy aronii może być zwiąany ze zmniejszeniem w śluzówce jelita cienkiego aktywności maltazy i sacharazy, jak również poprzez stymulację wychwytu glukozy, zwiększenie wydzielania hormonu anabolicznego insuliny oraz redukcje stresu oksydacyjnego (KOROTKIEWICZ i współaut. 2010 Z tego względu aronia jest cennym uzupełnieniem diety diabetyków. Jedna $z$ zalet soku $z$ aronii jest obniżenie indeksu glikemicznego (IG) (OsZMiańSKI i współaut. 2011). Pomiar indeksu glikemicznego (IG) został wykonany u osób w różnym wieku, którym podano do wypicia standardowy roztwór glukozy lub sok aroniowy $z$ ta sama zawartościa cukrów. U wszystkich badanych pijacych sok stwierdzono obniżenie wchłaniania cukru, w porównaniu $z$ osobami pijacymi roztwór zawierajacy $50 \mathrm{~g}$ glukozy. U badanych w wieku 20-30 lat IG wynosił 60,2- 63,5, a u osób w wieku 60 lat 46,8. Stwierdzono także, że antocyjaniny stymuluja wydzielanie insuliny (JAYAPRAKASAM i współaut. 2005). W badaniach in vitro działano na komórki trzustki 9 różnymi antocyjaninami; okazało się, że wydzielanie insuliny najsilniej stymuluja cyjanidyny $i$ delfinidyny, $z$ których cyjanidyna (aglikon) jest dominujaca antocyjanidyna w aronii (GAWRYŚ i współaut. 2012). Antocyjaniny działaja również przeciwzapalnie poprzez blokowanie ekspresji indukowanej syntazy tlenku azotu oraz cyklooksygenazy II (COX-2), w wyniku czego dochodzi do hamowania uwalniania pirogennej prostaglandyny (PGE2) i znacznego obniżenia wytwarzania tlenku azotu (ZIELIŃSKA-PRZYJEMSKA i współaut. 2007). Aronia odgrywa istotna rolę $\mathrm{w}$ diecie pacjentów $\mathrm{z}$ zespołem metabolicznym, ponieważ poza redukcja stężeń cukrów i cholesterolu we krwi, obniżaniu ciśnienia krwi, posiada także właściwości przeciwzapalne (ZAPOLSKA-DOWNAR i współaut. 2012).

\section{OBNIŻENIE RYZYKA POWSTAWANIA CHORÓB SERCOWO-NACZYNIOWYCH}

Kolejna korzystna dla zdrowia właściwością owoców aronii jest zmniejszenie ryzyka powstawania chorób sercowo-naczyniowych. W testach in vitro polifenole wykazały zdolność do ochrony i regeneracji komórek śródbłonka, tym samym poprawy ich funkcjonalności. W badaniach przeprowadzonych na ludziach i na zwierzętach, potwierdzono korzystne działanie aronii w hiperlipidemii oraz w hipercholesterolemii (KULLING i RAWEL 2008). Zwiazki polifenolowe hamuja perok- 
sydację lipoprotein o niskiej gęstości (LDL) (BIAŁEK i współaut. 2012), obniżają stężenie 8-izoprostanów i skutkuja wzrostem poziomu adiponektyny w surowicy, co przekłada się na redukcję stresu oksydacyjnego i zapalenia śródbłonka (KoROTKIEWICZ i współaut. 2010), obniżaja także ciśnienie tętnicze skurczowe i rozkurczowe poprzez hamowanie konwertazy angiotensyny (KULLING i RAWEL 2008, MAJEWSKA i CZECZOT 2009).

\section{DZIAŁANIE PRZECIWNOWOTWOROWE}

Polifenole sa to związki wykazujace działanie chemoprewencyjne (NARUSZEWICZ i KOZŁOWSKA-WOJCIECHOWSKA 2005), ale ich efektywność zależy od struktury chemicznej (KoROTKIEWICZ i współaut. 2010). Owoce aronii, podobnie jak i ekstrakty $z$ nich, wykazuja działanie antyproliferacyjne i ochronne $\mathrm{w}$ przypadku raka jelita grubego (BIAŁEK i współaut. 2012). Ekstrakt $z$ aronii może wypływać na tempo wzrostu niektórych typów raka piersi i okrężnicy, w wyniku hamowania sulfotransferazy - enzymu zaangażowanego w obniżenie poziomu estrogenów (KoROTKIEWICZ i współaut. 2010). Działanie przeciwnowotworowe możliwe jest również poprzez hamowanie aktywności enzymów, które biora udział w replikacji DNA (KULLING i RAWEL 2008). Zostało to potwierdzone badaniami na komórkach L1210 białaczki mysiej (KoROTKIEWICZ i współaut. 2010). Antocyjaniny obecne w soku $z$ aronii hamowały także rozwój i stopień nasilania się skutków ubocznych w momencie przyjmowania alkilujących leków przeciwnowotworowych (NIEDWOROK 2001).

\section{CZARNY BEZ}

Czarny bez (Sambucus nigra L.) znany także jako dziki bez, bez apteczny, bez pospolity, holunder czy hyćka (ANTKOWIAK 1998), to krzew lub niewielkie drzewo $z$ rodziny piżmaczkowatych (Adoxaceae) (SENDERSKI 2009). Rośnie w Europie w strefie umiarkowanej, w zachodniej i centralnej Azji oraz północnej Afryce (NowAK i NAWROT 2009). Roślina charakteryzuje się czarnymi, rosnącymi w gronach owocami o nieprzyjemnym zapachu. Owoce czarnego bzu stanowia surowiec zielarski, barwierski, spożywczy (KoZŁOWSKI 2002). Ponadto, jest to także roślina jadalna i ozdobna, $z$ zastosowaniem w kosmetyce. Owoce wykorzystywane sa w przetwórstwie spożywczym do wyrobu soków, syropów, win, marmolad, dżemów, powideł, galaretek, cukierków czy deserów. Z owoców i kwiatów bzu sporządza się herbaty ziołowe, owocowe, a także napary. Ponadto, destylaty z kwiatów bzu znajduja zastosowanie jako czynniki aromatyzujace wina gazowane, na- poje, jogurty czy lody, zaś ekstrakty wykorzystywane sa w napojach bezalkoholowych, przy produkcji lodów, jogurtów, herbat, win, a także ciast (KoŁODZIEJ i DROŻDżAL 2011). Co ciekawe, starożytni Rzymianie używali czarny bez do farbowania włosów (PIĄTKOWSKA i współaut. 2011). Sok z czarnego bzu charakteryzuje się ok. 10\% udziałem cukru i kwasowościa poniżej 1\%, przy znacznej ilości barwników. W kwiatach występują duże ilości glikozydów flawonoidowych, zwłaszcza astragalina i hiperozyd, trójterpeny i kwasy fenolowe, jak również sole mineralne, głównie potasowe (BLUMENTHAL i współaut. 2000). $\mathrm{Z}$ uwagi na skład owoców, które zawieraja od $0,2 \%$ do $1 \%$ antocyjanów i ok. 0,01\% olejku eterycznego, sa one wykorzystywane jako naturalne barwniki i aromaty produktów spożywczych (KOŁODZIEJ i DROżDżAL 2011). Czarny bez powoduje zwiększona peroksydację kwasu linolowego, w wyniku średniej i wysokiej aktywności antywolnorodnikowej (GAZZANI i współaut. 1998).

\section{PROZDROWOTNE WŁAŚCIWOŚCI CZARNEGO BZU}

Czarny bez jest jedna $z$ najstarszych roślin wykorzystywanych w leczeniu wielu schorzeń. Hipokrates zalecał preparaty $z$ czarnego bzu jako środek przeczyszczający i jako lek moczopędny (JANDA-ULFIG 2007).

\section{WŁAŚCIWOŚCI ANTYOKSYDACYJNE}

Właściwości prozdrowotne czarnego bzu zwiąane sa $z$ wysoka zawartościa polifenoli (naturalnych przeciwutleniaczy), które eliminuja wolne rodniki i zapobiegaja powstawaniu stresu oksydacyjnego, odpowiedzialnego za wywoływanie wielu chorób (GOLLUCKE i współaut. 2013).

\section{WŁAŚCIWOŚCI ODKWASZAJĄCE}

Owoce jagodowe, takie jak czarny bez, czarna porzeczka, winogrona czy maliny, sa bogatym źródłem witaminy $\mathrm{C}$, pektyn i łatwo przyswajalnych cukrów. Owoce maja działanie odkwaszajace ze względu na bogactwo składników mineralnych, przede wszystkim potasu, wapnia, magnezu i żelaza, a w nieco mniejszych ilościach cynku, miedzi i manganu (BOROWSKA i SZAJDEK 2005).

\section{WŁAŚCIWOŚCI PRZECIWWIRUSOWE I PRZECIWBIEGUNKOWE}

Czarny bez wykazuje działanie napotne, stosowany jest w leczeniu przeziębien, w stanach zapalnych żołądka i jelit (PIĄTKOWSKA i współaut. 2011), ma też właściwości odtruwające, wzmacniajace i uszczelniajace naczynia krwionośne (KoŁODZIEJ i DROŻDŻAL 2011). Ponadto, wykazuje działanie antywi- 
rusowe, antybakteryjne, immunostymulujące, antyoksydacyjne, a także obniżajace poziom cholesterolu, lipidów i cukru we krwi (ZIELIŃSKA-PISKLAK i współaut. 2013). Owoce bzu czarnego w nieco większych dawkach działaja przeczyszczająco, ułatwiajacc pozbycie się szkodliwych metabolitów, a także przeciwbólowo (spowalnianie reakcji), nie powodując jednocześnie skutków ubocznych uzależnienia.

\section{INNE WŁAŚCIWOŚCI LECZNICZE CZARNEGO BZU}

Pozytywne działanie czarnego bzu stwierdzono przy migrenach, bólach reumatycznych, nerwobólach, stanach zapalnych nerwu trójdzielnego i kulszowego, a także po zabiegach dentystycznych. Dodatkowo, owoce w mieszankach ziołowych reguluja pracę układu trawiennego, immunologicznego, moczowo-płciowego, stymuluja czynność nerek i wątroby oraz poprawiaja wydalanie toksyn po antybiotykoterapii. Owoce sa składnikami stosowanymi w preparatach wykorzystywanymi do leczenia chorób skóry, zwłaszcza łuszczycy, przy obrzękach oraz w zaparciach (WIERZBICKI 2002, WÓJCIK 2002, HEARST i współaut. 2010).

\section{ŻURAWINA}

Żurawina (d. Oxycoccus, właśc. Vaccinium sect. Oxycoccus) zaliczana jest do rodziny wrzosowatych (Ericaceae) $z$ rodzaju borówka (Vaccinium). Wyróżnia się dwa gatunki żurawiny: wielkoowocowa (V. macrocarpon) i błotna ( $V$. oxycoccus). Oba gatunki występuja w Polsce, w borach bagiennych oraz na torfowiskach przejściowych i wysokich (SZWEYKOWSKA i SZWEYKOWSKI 2003). Żurawina charakteryzuje się kulistymi, czerwonymi owocami o średnicy do $1 \mathrm{~cm}$, o cienkiej i gładkiej skórce. Jest wieloletnim, niskopiennym i wiecznie zielonym krzewem (TELESZKO 2011). Rośnie w klimacie umiarkowanym na półkuli północnej: w Azji, Ameryce Północnej, a także w środkowej i północnej Europie (GRYSZCZYŃSKA 2010). Owoce żurawiny są cennym źródłem witamin A, C i E oraz luteiny i beta-karotenu, sa również bogate w składniki mineralne takie jak: potas, sód czy selen. Najważniejszą grupa zwiąków prozdrowotnych obecnych w owocach żurawiny sa polifenole: flawonoidy, stilibeny i kwasy fenolowe (MCKAY i BLUMBERG 2007). Ponadto zawieraja liczne kwasy organiczne: kwas cytrynowy, chinowy, ursolowy i benzoesowy, co wpływa na ich specyficzny smak (SZWEYKOWSKA i SZWEYKOWSKI 2003). Żurawina jest surowcem stosowanym w wielu gałęziach przemysłu m.in.: w przemyśle spożywczym, farmaceutycznym, kosmetycz- nym. Wykorzystywana jest do produkcji suplementów diety. $Z$ owoców żurawiny sporządza się galaretki, konfitury, dżemy, syropy, nalewki, wina, soki, kisiele, ale także sosy, które stanowia tradycyjny dodatek do mięs (VAUGHAN i GeISSLER 2001). W handlu dostępna jest żurawina suszona, która można dodawać do wypieków, deserów, lodów i sosów.

\section{PROZDROWOTNE WŁAŚCIWOŚCI ŻURAWINY}

Indianie $z$ Nowej Anglii wykorzystywali żurawinę nie tylko do leczenia, ale również w codziennej diecie, handlu czy regulowaniu rachunków. $Z$ żurawiny przygotowywano kataplazmy do leczenia ran i zakażenia krwi, a liści używano do leczenia zakażeń układu moczowego, cukrzycy czy biegunki (HENIG i LEAHY 2000). Owoce były także wykorzystywane w leczeniu chorób żołądka, krwi, wątroby, goraczki, szkorbutu (LOWE i FAGELMAN 2001). Żurawina wykorzystywana jest obecnie w leczeniu choroby wrzodowej, przyzębia, arteriosklerozy i choroby nowotworowej (GRAJEK 2007).

\section{WŁAŚCIWOŚCI PRZECIWZAPALNE}

Badania przeprowadzone na myszach ze stanem zapalnym jelita grubego potwierdzaja właściwości przeciwzapalne żurawiny (TELESZKo 2011). Wniknięcie do układu moczowego bakterii, najczęściej Escherichia coli, skutkuje stanem zapalnym, który charakteryzuje się bólem i częstym parciem na oddawanie moczu. Na infekcje dróg moczowych częściej cierpia kobiety niż mężczyźni, częstość zakażeń wzrasta $z$ wiekiem. Ponad $40 \%$ kobiet przyznało, że spotkało się $z$ tym problemem co najmniej raz w życiu. Okazuje się, że picie soku $z$ żurawin zmniejsza liczbę bakterii podczas przebiegajacej infekcji, wspomagajac kurację antybiotykami, a regularne picie soku przez dłuższy czas powstrzymuje nawrót infekcji (WALKER i współaut. 1997). Antybakteryjny efekt leczenia wynika $z$ antyadhezyjnego działania soku żurawinowego (HowELL i współaut. 1998). Sok żurawinowy powoduje, że bakterie $E$. coli zmieniaja kształt, traca wyrostki, które umożliwiaja im przyczepność do podłoża i rozrost kolonii (AHUJA i współaut. 1998). Zwiazek działajacy antyadhezyjnie to polimer proantocyjanidynowy, który składa się $z \quad 4$ lub 5 jednostek epikatechiny (FOO i współaut. 2000).

\section{WŁAŚCIWOŚCI PRZECIWMIAŻDŻYCOWE}

Żurawina wykazuje również działanie przeciwmiażdżycowe i hamuje jej skutki w układzie krażenia. Przed ryzykiem wystapie- 
nia miażdżycy chroni dieta bogata w antyoksydanty. Dowody na to, że sok żurawinowy jest silnym antyoksydantem wykazano w testach z ludzkim „złym” cholesterolem (ang. low-density lipoprotein cholesterol, LDL) (Foo i współaut. 2000).

\section{WŁAŚCIWOŚCI PRZECIWREUMATYCZNE}

Reumatoidalne zapalenie stawów (RZS) to częsta choroba diagnozowana u kobiet w wieku średnim. Badania mikrobiologiczne i immunologiczne wykazały bezpośrednia korelacje pomiędzy obecnością bakterii Proteus mirabillis a RZS. Powtarzające się zakażenia dróg moczowych są czynnikiem drażniącym, skutkującym produkcją przeciwciał i reakcji autoimmunologicznej. Osoby w początkowych stadiach rozwoju RZS zaobserwowały wyraźna poprawę swego stanu pijąc sok $Z$ żurawiny (EBRINGER i RASHID 2006).

\section{PROZDROWOTNY WPŁYW ŻURAWINY NA KONDYCJE SKÓRY}

Żurawina od lat wykorzystywana i znana w medycynie jako roślina, wspomagajaca leczenie wielu schorzeń, doceniana została również jako surowiec kosmetyczny. Owoce żurawiny bogate sa w związki bioaktywne, witaminy i sole mineralne, które maja pozytywny wpływ na kondycję skóry i nasze zdrowie. Żurawina zalecana jest do pielęgnacji cery suchej, dojrzałej, $z$ przebarwieniami, trądzikowej, zanieczyszczonej, a także wymagajacej odnowy (LEGAN 2009). Obecnie na rynku dostepne sa preparaty farmaceutyczne zawierające ekstrakt bądź zagesszczony sok $z$ żurawiny, które sa pomocne w terapii uzupełniajacej wielu chorób skóry (MICHALAK i współaut. 2016).

\section{JAGODA KAMCZACKA}

Jagoda kamczacka (Lonicera caerulea L. var. Kamtschatica Sevast.) to roślina owocodajna, długowieczna. Jest odmiana wiciokrzewu sinego (Lonicera caerulea), z rodziny przewiertnikowatych (Caprifoliaceae Juss). W Polsce występuje pod nazwa wiciokrzew kamczacki, pochodzi $z$ północno-wschodniej Azji. Owoc jagody kamczackiej to wydłużona, mięsista, wielonasienna niby-jagoda koloru fioletowoczarnego, o niebieskim, woskowym nalocie. Jej owoce występują w różnych kształtach: owalnym, kubkowatym, czy walcowato-elipsoidalnym o długości od 1,5 do $2,5 \mathrm{~cm}$ i szerokości do $1 \mathrm{~cm}$ (SzOT i LIPA 2012). Dojrzałe owoce wykorzystywane sa w przemyśle spożywczym do produkcji dżemów, soków, nalewek, suszu czy mrożonek. Stanowia również dodatek do deserów. Maja także zastosowanie jako składniki suplementów diety i preparatów leczniczych (SzOT i współaut. 2014). Ponadto, z owoców otrzymuje się czerwony, naturalny barwnik spożywczy (Fu i współaut. 2011). Jagoda kamczacka, oprócz tego, że jest źródłem witaminy $\mathrm{C}$, zawiera polifenole, w tym antocyjany takie jak: glikozydy i rutynozydy cyjanidyny, delfidyny, peonidyny i pelargonidyny. W jej składzie obecne sa także kwasy: chlorogenowy, kawowy i ferulowy, ale to antocyjany przeważaja w zewnętrznej części owoców (SzOT i współaut. 2014).

\section{PROZDROWOTNE WŁAŚCIWOŚCI JAGODY KAMCZACKIEJ}

Zwiąki aktywne owoców jagody kamczackiej absorbowane w żołąku i jelicie cienkim wykazują działanie przeciwmiażdżycowe. Udowodniono, że produkty bogate w antocyjany maja pozytywny wpływ na profil lipidowy i redukują stres oksydacyjny.

\section{WSPOMAGANIE LECZENIA CHORÓB OCZU}

Jagoda kamczacka wspomaga leczenie chorób oczu, bowiem zmniejsza kruchość kapilar włosowatych, poprawia przepuszczalność śródbłonka, wyostrza wzrok po zmroku oraz reguluje niektóre dolegliwości wzroku (SzOT i współaut. 2014).

\section{WŁAŚCIWOŚCI PRZECIWNOWOTWOROWE}

Jagoda kamczacka wykazuje działanie przeciwnowotworowe, $z$ uwagi na antocyjany, które powoduja dezaktywację wolnych rodników tlenowych (GRAJEK 2004). Badania SzOT i współaut. (2014) wykazały, że antocyjany wyizolowane $z$ owoców jagody posiadały zdolność antyproliferacyjną w różnych komórkach nowotworowych (SzOT i współaut. 2014).

\section{DZIAŁANIE PRZECIWBAKTERYJNE I PRZECIWWIRUSOWE}

Roślina ta ma szerokie spektrum zastosowań w leczeniu infekcji bakteryjnych i wirusowych, a także chorób krwi. Posiada właściwości odtruwające; owoce stosowane sa w przypadku zatruć metalami ciężkimi i lekami syntetycznymi. Sok $z$ owoców jagody kamczackiej może być stosowany przy leczeniu wrzodów i liszajców, a wywar stosuje się w formie płukanek jamy ustnej i gardła przy nieżytach, chorobach dziąseł $i$ anginie (KAWECKI i współaut. 2001). Na Dalekim Wschodzie i Syberii dojrzałe owoce wykorzystuje się w leczeniu opuchlizny wodnej. Jagody sa bogatym źródłem związków wzmacniających naczynia krwionośne, a także działaja przeciwsklerotycznie i przeciwzapalnie. Najnowsze badania potwierdzaja skuteczne działanie antyzapalne jagód, jak również właściwości łagodzące przy dolegli- 
wościach pokarmowych o podłożu alergicznym (Szot i współaut. 2014).

\section{MALINA WŁAŚCIWA}

Malina właściwa (Rubus idaeus L.) należy do roślin strefy umiarkowanej $\mathrm{z}$ rodziny różowatych (Rosaceae). Uprawiana jest w strefach chłodniejszych i subarktycznych Azji, Europy i Ameryki Północnej, Australii, Nowej Zelandii oraz w Chinach. W Polsce występuje na terenie całego kraju w lasach, na wyrębach, na polanach, na nizinach i w górach (BARANOwSKA i współaut. 2015). W produkcji maliny właściwej Polska zajmuje pierwsze miejsce $\mathrm{w}$ Europie, a trzecie na świecie (DANEK 2009). Malina zaliczana jest do krzewów wieloletnich, o wysokości do 2 $\mathrm{m}$. Jej owoce należą do grupy owoców zbiorowych; sa to małe, czerwone, pokryte delikatnym meszkiem owoce typu pestkowiec, potocznie zwane "malinami” (BARANOWSKA i współaut. 2015). "Owoce można spożywać na surowo $\mathrm{i} \mathrm{w}$ postaci przetworów (GRYSZCZYŃSKA i współaut. 2011): dżemów, marmolad, konfitur, soków, syropów, nalewek, win oraz dodatków do ciast, lodów czy deserów. W leczeniu różnych dolegliwości wykorzystywane sa nie tylko świeże i suszone owoce, lecz również suszone liście i pędy (DYMARSKA i współaut. 2016). Owoce malin sa bogatym źródłem witaminy $\mathrm{C}, \mathrm{E}, \mathrm{B} 1, \mathrm{~B} 2$ i $\mathrm{B} 6$, składników mineralnych $\mathrm{Ca}, \mathrm{K}, \mathrm{Fe}, \mathrm{Cu}$ czy Mn, zawieraja również dużą ilość pektyn, substancji sluzowatych i błonnika $(7 \%)$ (BARANOWSKA i współaut. 2015). Ponadto, sa naturalnym źródłem polifenoli: kwasów fenolowych, antocyjanów, flawonów, tanin i $\beta$-sitosteroli. W owocach całkowita zawartość polifenoli wynosi $140-662 \mathrm{mg} / 100 \mathrm{~g}$ świeżego produktu, na co wpływaja czynniki genetyczne i środowiskowe (DYMARSKA i współaut. 2016). Z kolei zawartość antocyjanów sięga $40-100 \mathrm{mg} / 100 \mathrm{~g}$ świeżego produktu czy soku. Główne antocyjany obecne w malinie właściwej to: wolna cyjanidyna, 3-glukozylorutozyd cyjanidyny, 3-glukozyd cyjanidyny, 3-rutozyd cyjanidyny, natomiast w mniejszych stężeniach: malwidyny, pelargonidyny, a także delfinidyny. Maliny sa również jedynym, bogatym źródłem elagotanin (KRAUZE-BARANOWSKA 2007).

\section{PROZDROWOTNE WŁAŚCIWOŚCI MALINY WEASCIWEJ}

Malina właściwa uznawana jest od dawna za owoc o działaniu przeciwzapalnym, przeciwgorączkowym, ściagającym oraz jako środek normalizujacy prace układu pokarmowego i przemianę materii (KRAUZE-BARANOWSKA i współaut. 2014). Owoce wykorzy- stywane sa w leczeniu przeziębień, grypy, przy infekcjach wirusowych czy bakteryjnych, $z$ towarzyszaca gorączka i w chorobach nerek (KRAUZE-BARANOWSKA i współaut. 2014, BARANOWSKA i współaut. 2015). $\mathrm{Na}$ bazie owoców maliny produkowane sa syropy dla dzieci. Dzięki obecnym w suszonych owocach olejkom eterycznym o właściwościach rozgrzewajacych i antyseptycznych, wchodza w skład mieszanek przeciwgoraczkowych i napotnych. $Z$ kolei liście są składnikiem mieszanek żółciopędnych i moczopędnych. Coraz większe zainteresowanie budzi olejek $z$ nasion malin, który w swoim składzie zawiera niezbędne nienasycone kwasy tłuszczowe (NNKT), witaminy $\mathrm{i}$ antyoksydanty. Ponadto, owoc charakteryzuje się działaniem antyoksydacyjnym, przeciwdrobnoustrojowym i przeciwnowotworowym. Polifenole uniemożliwiaja powstawanie wolnych rodników, które utleniaja wiele zwiazków w naszym organizmie oraz niszcza białka, tłuszcze, błony komórkowe, materiał genetyczny i enzymy (KRAUZE-BARANOWSKA i współaut. 2014).

\section{WŁAŚCIWOŚCI PRZECIWREUMATYCZNE}

Przeprowadzono badania in vitro $\mathrm{i}$ in vivo, w których badano właściwości przeciwreumatyczne wyciagu $z$ owoców maliny. Celem badań była ocena efektów przeciwzapalnych i chroniacych chrzastkę stawowa $\mathrm{w}$ modelu in vitro $\mathrm{z}$ wykorzystaniem hodowli chrząstki przegród nosowych bydła oraz $\mathrm{w}$ modelu in vivo $z$ adiuwantem indukowanej artrozy u szczurów. Wykorzystano ekstrakty w dawkach 30 i $120 \mathrm{mg} / \mathrm{kg}$ podawanych w ciagu miesiaca po zastosowaniu adiuwanta. Wykazano, że ekstrakt podany w wyższych dawkach hamuje rozwój choroby, mierzony stopniem obrzęku łapy szczura, bez spadku masy ciała charakterystycznego dla tego modelu badawczego. $\mathrm{W}$ modelu in vitro $\mathrm{w}$ hodowli chrząstki, po dodaniu do podłoża standaryzowanego ekstraktu $z$ owoców malin w stężeniu $50 \mathrm{\mu g} / \mathrm{ml}$ zaobserwowano hamowanie procesu degradacji zarówno proteoglikanu, jak i kolagenu typu II (JEAN-GILLES i współaut. 2012).

\section{WŁAŚCIWOŚCI WSPOMAGAJĄCE LECZENIE OTYŁOŚCI}

Istnieja doniesienia o korzystnym działaniu ketonu malinowego $\mathrm{w}$ leczeniu otyłości i w kuracjach odchudzajacych. Keton malinowy jest to główny zwiazek aromatyczny w owocach malin, wykorzystywany w przemyśle perfumeryjnym i w aromatach spożywczych. Badania przeprowadzone na szczurach na diecie bogatotłuszczowowej, $z$ ketonem malinowym $1 \%$, wykazały zahamowanie wzrostu podskórnej tkanki tłuszczowej. Dodatkowo, 
keton zredukował wysoki poziom triacylogliceroli, wywołany dieta wysokotłuszczowa. $Z$ uwagi na podobna strukturę, keton malinowy został porównany do dwóch substancji wspomagajacych odchudzanie, synefryny i kapsaicyny, i sugeruje się, że działa on $\mathrm{w}$ ten sam sposób (KRAUZE-BARANOWSKA i współaut. 2014).

\section{PODSUMOWANIE}

Opisane owoce krajowe o szerokich właściwościach prozdrowotnych, są źródłem cennych związków, takich jak witaminy, minerały, antyoksydanty. Zarówno świeże, jak i suszone owoce powinny urozmaicać nasza codzienna dietą, ponieważ są cennym surowcem zapobiegajacym wielu chorobom i wspomagającym ich leczenie.

$$
\text { Streszczenie }
$$

Owoce i ich przetwory stanowia źródło cennych i niezbędnych substancji odżywczych. Sa niskokaloryczne, bogate w witaminy, zwiazki mineralne, błonnik pokarmowy, pektyny, łatwo przyswajalne cukry i kwasy organiczne. Zawieraja wiele substancji bioaktywnych, np. polifenole czy fitoestrogeny, odpowiedzialne za ich właściwości prozdrowotne. Odpowiednia ilość owoców w diecie jest szczególnie ważna dla utrzymaniu prawidłowego stanu zdrowia. Dobór surowców o największej wartości odżywczej, bogatych w wiele substancji naturalnie aktywnych stanowi o właściwościach i jakości owoców. Szczególna uwagę należy zwrócić na owoce krajowe, których dostępność dla konsumentów jest większa, a krótszy okres przechowywania oraz transportu czynni je atrakcyjnym i wartościowym surowcem.

Celem pracy było przedstawienie właściwości prozdrowotnych wybranych owoców uprawianych w Polsce: aronii, czarnego bzu, żurawiny, jagody kamczackiej i maliny właściwej, ze względu na ich właściwości profilaktyczne w leczeniu wielu chorób i schorzeń.

\section{LITERATURA}

AHUJA S., KAACK B., RoBerTS J., 1998. Loss of fimbrial adhesion with the addition of Vaccinum macrocarpon to the growth medium of P-fimbriated Escherichia coli. J. Urol. 159, 559-562.

ANTKOWIAK L., 1998. Rośliny lecznicze. Wydawnictwo Akademii Rolniczej im. Augusta Cieszkowskiego w Poznaniu, Poznań.

Aune D., Giovannucci E., Boffetta P., Fadnes L. T., KEUM N., NORAT T., GREENWOOD D. C., RIBOLI E., VATTEN L. J., TONSTAD S., 2017. Fruit and vegetable intake and the risk of cardiovascular disease, total cancer and all-cause mortality - a systematic review and dose-response meta-analysis of prospective studies. Int. J. Epidemiol., https://doi.org/10.1093/ ije/dyw319.

BARANOWSKA A., RADWAŃSKA K., ZARZECKA K., GUGAEA M., MYSTKOWSKA I., 2015. Właściwości prozdrowotne owoców maliny właściwej (Rubus idaeus L.). Probl. Hig. Epidemiol. 96, 406-409.

BiateK M., RuTKOwska J., Hallmann E., 2012. Aronia czarnoowocowa (Aronia melanocarpa) jako potencjalny składnik żywności funkcjonalnej. Żywność Nauka Technologia Jakość 6, 21-30.

BlumENTHAL M., GOLDBERG A., BRINCKANN J., 2000. Herbal medicine: expanded commission E monographs. American Botanical Council.

Borowska E. J., SzAJDEK A., 2005. Składniki dietetyczne $i$ substancje biologiczne $w$ owocach aronii, borówki czernicy i porzeczki czarnej. Bromat. Chem. Toksykol. Suppl., 181-184.

DANEK J., 2009. Uprawa maliny $i$ jeżyny. Hortpress, Warszawa.

Dymarska E., Grochowalska A., KraUss H., CheCIŃSKA-MACIEJEWSKA Z., 2016. Naturalne modyfikatory odpowiedzi immunologicznej. Probl. Hig. Epidemiol. 97, 297-307.

EBRINGER A., RASHID T., 2006. Rheumatoid arthritis is an autoimmune disease triggered by Proteus urinary tract infection. Clin. Dev. Immunol. 13, 41-48.

Foo L. Y., LU Y., Howell A. B., Vorsa N., 2000. The structure of cranberry proanthocyanidins which inhibit adherence of uropathogenic $P$-fimbriated Escherischia coli in vitro. Phytochemistry 54, 173-181.

Fu L.S., OKAMOTO H., KataOKa T., Shibata Y., 2011. Color based classification for berries of Japanese blue honeysuckles. Int. J. Food Eng. 7, 131-135.

GAWRYS M., ZAWADA K., WAWER I., 2012. Aronia $w$ świecie diabetyków. Diabetol. Klin. 1, 196200.

Gazzani G., Papetti A., Massolini G., DaglaiA M., 1998. Anti- and prooxidant activity of water soluble components of some common diet vegetables and effect of thermal treatment. J. Agric. Food Chem. 46, 4118-4122.

GHERIBI E., 2011. Zwiazki polifenolowe $w$ owocach $i$ warzywach. Medycyna Rodzinna 4, 111-115.

Gollucke A. P., Peres R. C., OdAir A., Ribeiro D. A., 2013. Polyphenols: a nutraceutical approach against diseases. Rec. Patents Food Nutrit. Agricult. 5, 214-219.

GRAJEK W., 2004. Rola przeciwutleniaczy $w$ zmniejszaniu ryzyka wystapienia nowotworów $i$ chorób układu krażenia. Żywność Nauka Technologia. Jakość 1, 3-11.

GRAJEK W., 2007. Przeciwutleniacze $w$ żywności. Aspekty zdrowotne technologiczna, molekularne $i$ analityczne. Wydawnictwo Naukowo-Techniczne, Warszawa.

GRYSZCZYŃSKA A., 2010. Żurawina amerykańska (Vaccinium macrocarpon) - lek na problemy urologiczne. Przegląd urologiczny, http:// www.sunfarm.pl/library/2016/12/20/148223768464.pdf

GRYSZCZYŃSKA B., ISKRA M., GRYSZCZYŃSKA A., BUDZYŃ M., 2011. Aktywność przeciwutleniajaca wybranych owoców jagodowych. Post. Fitoter. $4,256-274$.

GWóżDź E., GĘBCZYŃSKI P., 2015. Prozdrowotne właściwości owoców, warzyw i ich przetworów. Post. Fitoter. 4, 268-271.

Hearst C., McCollum G., Nelson D., Ballard L. M., Millar B. C., Goldsmith C. E., RoOney P. J., LOUGHREY A., MOORE J. E., RAO J. R., 2010: Antibacterial activity of elder (Sambucus nigra L.) flower or berry against hospital pathogens. J. Med. Plants Res. 4, 1805-1809.

HeNiG Y. S., LEAHY M. M., 2000. Cranberry juice and urinaryO-tract health: science supports folklore. Nutrition 16, 684-687.

HOWELl A. B., VORSA N., MARDEROSIAN A. D., FOO L. Y., 1998. Inhibition of the adherence of P-fimbriated Escherichia coli to uro-epithelial 
surfaces by procyanidin extracts from cranberries. N. Engl. J. Med. 339, 1085-1086.

JANDA-Ulfig K., 2007. Dziki bez - czyli wiejska apteczka. Panacea.pl. 1, 16-17.

JAYAPRAKASAM B., VAREED S. K., Olson L. K., NAIR M. G., 2005. Insulin secretion by bioactive anthocyanins and anthocyanidians present in fruits. J. Agric. Food Chem. 53, 28-31.

JEAN-Gilles D., Li L., MA H., YUAN T., CHICHESTER C. O. 3RD, SEERAM N. P., 2012. Antiinflammatory effects of polyphenolic-enriched red raspberry extract in an antigen-induced arthritis rat model. J. Agric. Food Chem. 60, 575562.

KAWECKI Z., ŁoJKo R., PILAReK B., 2001. Mało znane rośliny sadownicze. Wyd. UWM, Olsztyn.

KMIECIK D., KoBUs J., 2005. Badanie postaw kon sumentów wobec przeciwutleniaczy. Żywność Nauka Technol. Jakość 2 (Suppl.), 308-317.

KoŁodZIEJ B., DROŻDŻAL K., 2011. Właściwości przeciwutleniajace kwiatów i owoców bzu czarnego pozyskiwanego ze stanu naturalnego. Żywność Nauka Technol. Jakość 4, 36-44

KOROTKIEWICZ A., JEREMICZ Z., LUCZKIEWICZ M., 2010. Aronia Plants: A review of traditional use, biological activities, and perspectives for modern medicine. J. Med. Food 13, 255-269.

KozŁOWSKI J., 2002. Rośliny bogate $w$ barwni$k i$ oraz ich znaczenie $i$ zastosowanie. Cz. I. Wiad. Ziel. 5, 9-12.

KRAUZE-BARANOWSKA M., 2007. Owoce maliny właściwości dietetyczne $i$ lecznicze. Panacea $21,22-23$.

KraUze-BARANOWSKa M., MAJDAN M., Kula M., 2014. Owoce maliny właściwej $i$ maliny $z a-$ chodniej źródłem substancji biologicznie aktywnych. Post. Fitoter. 1, 32-39.

Kulling S. E., RAWEL H. M., 2008. Chokeberry (Aronia melanocarpa) - A review on the characteristic components and potential health effects. Planeta Med. 74, 1625-1634.

KUZZNICKA B., DZIAK M., 1987. Zioła $i$ ich zastosowanie. PZWL, Warszawa.

LEGAN A., 2009. Żurawina - indiańska księżniczka jesieni. Med. Estet. Anti-Aging 4, 28-32.

LOWE F. C., FAGELMAN E., 2001. Cranberry juice and urinary tract infections: what is the evidence? Urology 57, 407-413.

MAJEWSKA M., CZECZOT H., 2009. Flawonoidy $w$ profilaktyce $i$ terapii. Farm. Pol. 65, 369-377.

MCKAY D. L., BlumberG J. B., 2007. Cranberries (Vaccinium macrocarpon) and cardiovascular disease risk factors. Nutr. Rev. 65, 490-502.

MichalaK M., PODSEDEK A., GLINKA R., 2016. Potencjat przeciwutleniajacy oraz zwiazki polifenolowe glikolowych ekstraktów z Hippophaë rhamnoides L. $i$ Vaccinium oxycoccos L. Post. Fitoter. 17, 33-38.

MiCHALIK B., 1999. Aronia - źródło zdrowia i młodości. Żyjemy dłużej 7, 16.

NARUSZEWICZ M., KOZEOWSKA-WOJCIECHOWSKA M., 2005. Potential pharapharmaceuticals in the traditional Polish diet. J. Physiol. Pharmacol. 56 (Suppl. 1), 69-78.

NiEDWOROK J., 2001. Właściwości lecznicze antocyjanin $z$ aronii czarno-owocowej. Farm. Pol. 57, 719-721.
NOWAK G., NAWROT J., 2009. Surowce $i$ zwiazki naturalne stosowane $w$ chorobach układu oddechowego. Herba Pol. 55, 179-203.

OSZMIAŃSKI J., NOWICKA P., RUBIŃSKI P., 2011. Aronia - niedoceniony $w$ Polsce owoc prozdrowotny. Przem. Ferm. Ow. Warz. 7-8, 4-18.

Piatkowska E., Kopeć A., LESZCZYŃSKA T., 2011. Antocyjany - charakterystyka, wystepowanie $i$ oddziaływanie na organizm człowieka. Żywność Nauka Technol. Jakość 4, 24-35.

SENDERSKI E. M., 2009. Zioła - praktyczny poradnik o ziołach $i$ ziołolecznictwie. Wydawnictwo Liber.

SKUPIEN K., OsZMiańsKI J., 2007. The effect of mineral fertilization on nutritive value and biological activity of chokeberry fruit. J. Argic. Food Sci. 16, 46-55.

SZAJDEK A., BOROWSKA J., 2004. Właściwości przeciwutleniajace żywności pochodzenia roślinnego. Żywność Nauka Technol. Jakość 4, 5-28.

SzOT I., LIPA T., 2012. Influence of betokson super and fertilizers on chemical composition of fruits and leaves of blue honeysuckle. Acta Sci. Pol., Hort. Cult. 11, 113-126.

SzOT I., LIPA T., SosnowsKA B., 2014. Jagoda kamczacka- właściwości prozdrowotne owoców $i$ możliwości ich zastosowania. Żywność Nauka Technol. Jakość 4, 18-29.

SZWEYKOWSKA A., SZWEYKOWSKI J., 2003. Słownik botaniczny. Wiedza Powszechna, Warszawa.

TELESZKO M., 2011. Żurawina wielkoowocowamożliwości wykorzystania do produkcji biożywności. Żywność Nauka Technol. Jakość 6, $132-141$.

Vaughan J. G., Geissler C. A., 2001. Rośliny jadalne. Prószyński i S-ka, Warszawa.

WALKER E. B., BARNEY D. P., MICKELSEN J. N., WALTON R. J., MICKELSEN R. A. JR., 1997. Cranberry concentrate: UTI prophylaxis. J. Fam. Pract. 45, 167-168.

WIERZBICKI A., 2002. Dziki bez czarny - pozyskiwanie surowca $i$ jego zastosowanie. Wiad. Zielar. 4, 8-10.

Wolski T., Kalisz O., Prasat M., Rolski A., 2007. Aronia czarnoowocowa - Aronia melanocarpa. (Michx) Ellioit- zasobne źródło antyoksydantów. Post. Fitoter. 3, 145-154.

WóJcik J., 2002. Nowe wskazania lecznicze Sambucus nigra L. Wiad. Zielar. 4, 11-12.

ZAPOLSKA-DOWNAR D., BRYK D., MAŁECKI M., HAJDUKIEWICZ K., SiTKIEWICZ D., 2012. Aronia melanocarpa fruit extract exhibits anti-inflammatory activity in human aortic endothelial cells. Eur. J. Nutr. 51, 563-572.

ZiElińSKA-PiSKlaK M., SZElESZCZuK Ł., MŁodZIANKA A., 2013. Bez czarny (Sambucus nigra) domowy sposób nie tylko na grypę. Lek. Pol. 23, $1-4$.

ZielińSKA-PRZyeJMSKa M., OleJNiK A., GRAJEK W., 2007. Wpływ soku $z$ buraka ćwikłowego $i$ aronii in vitro na metabolizm tlenowy $i$ apoptozę ludzkich granulocytów obojętnochłonnych. Żywność Nauka Technol. Jakość 51, 174-186. 
KOSMOS Vol. 67, 2, 415-423, 2018

Marta Doroszko, Katarzyna Janda, Karolina JaKUbCZyK

Department of Biochemistry and Human Nutrition, Pomeranian Medical University in Szczecin, Broniewskiego 24, 71-460 Szczecin, E-mail: kjanda4@gmail.com

\section{HEALTHY PROPERTIES OF SELECTED NATIONAL FRUITS}

\section{Summary}

Fruits and fruit preserves are the source of valuable and essential nutrients. They are low-calorific, rich in vitamins, minerals, dietary fiber, pectin, easily absorbed sugars and organic acids. They contain valuable bioactive substances such as polyphenols or phytoestrogens that are responsible for the health benefits of fruits. The right amount of them in a diet is especially important for maintaining good health. Selection of the most nutritious raw materials, rich in many naturally occurring substances, is the property and quality of the fruit. Particular attention should be paid to domestic fruits, whose greater accessibility for consumers, shorter shelf -life and transport make them more attractive and valuable raw materials.

The aim of this paper was to present the pro-health properties of selected fruits cultivated in Poland: black chokeberry, elderberry, cranberry, honeyberry and raspberry, because of their valuable prophylactic properties in the treatment of many diseases.

Keywords: bioactive components, fruits, health properties 